\title{
Notes on Secondary Batteries
}

This content has been downloaded from IOPscience. Please scroll down to see the full text. 1888 Proc. Phys. Soc. London 10448

(http://iopscience.iop.org/1478-7814/10/1/360)

View the table of contents for this issue, or go to the journal homepage for more

Download details:

IP Address: 192.236.36.29

This content was downloaded on 06/09/2015 at 10:33

Please note that terms and conditions apply. 
LIX. Notes on Secondary Batteries. By J. H. GLadstontr, Ph.D., F.R.S., and W. HibBert, F.I.C.*

Ejgrt years ago, one of us, in conjunction with the late Mr. Tribe, published a series of papers on the Chemistry of Secondary Batteries $t$. Since that time accumulators have undergone many improvements in detail, but they still present some unsolved problems of a more or less subtle character. In this paper we give an account of some experiments undertaken to test points which have arisen. in the last few years.

\section{Action of Sodium Sulphate.}

In May $1889 \mathrm{Mr}$. Preece delivered a lecture at the Society of Arts dealing generally with his experience of Secondary Batteries Among the topics treated was the influence of the compcsition of the electrolyte on the working of the cell, and it was stated that the addition of sodium sulphate to the acid solution was of very considerable advantage. Mr. Preece determined the proportions of acid and sulphate which gave the best result in a year's working, and found that a comparatively small quantity of the salt was sufficient to produce the effect.

We have determined the percentage composition of the liquid from a sample kindly furnished by Mr. Preece, and find it to be as follows :-

$$
\begin{aligned}
& \text { Sodium sulphate }\left(\mathrm{Na}_{2} \mathrm{SO}_{4}\right) \quad \cdot \quad 0.81 \\
& \text { Sulphuric acid }\left(\mathrm{H}_{2} \mathrm{SO}_{4}\right) \text {. } 29 \cdot 39 \\
& \text { Water . . . . . } 69.80 \\
& 100 \cdot 00
\end{aligned}
$$

The specific gravity at ordinary temperatures is about $1 \cdot 23 \ddagger$. When used in secondary batteries instead of the usual acid,

* Read June 20, 1890.

† Nature, 1882 and 1883, vols. xxr. and xavi.; afterwards published by Macmillan.

I In making this liquid, it would be best to add together 68 parts (by weight) of water, 30 of strong sulphuric acid, and 2 parts of crystallized sodium sulphate $\left(\mathrm{Na}_{2} \mathrm{SO}_{4} \cdot 10 \mathrm{H}_{2} \mathrm{O}\right)$. 
it is stated that there is less buckling of the plates and little or no scaling. The chief benefit, however, is stated to be that the sodium salt diminishes the chance of objectionable sulphating in the cell, and where such sulphating occurs, enables it to be removed by a charging current much more readily than when sulphuric acid alone is employed.

Mr. Preece did not explain the beneficial action of the sodium sulphate, but in the discussion following the lecture Sir F. Abel threw out the idea that it was "probable that a double salt of sulphate of lead and sodium was formed which was soluble, whereas the sulphate of lead was comparatively insoluble."

We have made some experiments to test the value of this suggestion. It may be well, however, to note that lead sulphate is so nearly insoluble in dilute sulphuric acid that comparatively large errors are easily possible.

We took advantage of the greater solubility of lead sulphate in strong acid. Measured volumes of this were added to water, the precipitate formed allowed to settle, and the lead salt remaining in solution determined by precipitation as sulphide.

The mean results are:-1 part of lead sulphate dissolves in 105,000 parts of the acid mixed with water, in 90,000 parts of a similarly diluted acid containing 5 per cent. sodium sulphate, and in 107,000 parts of Mr. Preece's solution.

As these numbers deal with such minute quantities we lay no stress on their absolute value. Their relative values are more useful, and evidently the addition of the sodium salt has not materially increased the solubility of lead sulphate.

This conclusion was confirmed by experiments of another type. To equal quantities of a dilute acid and a similar acid containing sodium sulphate we added a few drops of strong acid saturated with lead sulphate. Precipitates were formed in both cases, but it was possible so to adjust the number of drops that the precipitate did not appear for an appreciable time. We could therefore see in which it appeared first. In many experiments and many variations of procedure, we nearly always obtained earlier precipitation in liquids containing sodium or magnesium sulphates than in those consisting simply of dilute acid. We judge therefore that lead sulphate is not more soluble in these liquids, and that the explanation 
of the action of sodium sulphate must be sought in some other direction.

Mr. Swinburne has suggested that, as lead sulphate is dissolved by sodium hydrate, the action may be due to that hydrate being produced by electrolysis of the sodium sulphate. Experiment showed that in a simple solution of neutral sulphate of soda, a paste made of equal parts of red lead and sulphate of lead was more readily reduced than in dilute sulphuric acid. It was also easy to detect sodium hydrate on the cathode by red litmus-paper. But this last result was no longer obtained when the sodium-sulphate solution contained sulphuric acid in the proportion of 1 volume to 10 . The acid present interferes with such a simple test, and we sought for information on the point by determining the ratio of acid to sulphate of soda in the pores of the spongy lead, and comparing it with the ratio of the same substances in the body of the liquid. Preliminary experiments indicated the following as the best course to pursue.

A strip of spongy lead was used as cathode in a liquid somewhat similar to that analysed above. The ratio was $\frac{\mathrm{H}_{2} \mathrm{SO}_{4}}{\mathrm{Na}_{2} \mathrm{SO}_{4}}=30$. A current was passed for three hours, falling slowly from about 2 amperes to $1 \cdot 5$. The strip was then taken out and placed in 120 cubic centim. of distilled water and allowed to diffuse for 40 minutes. It was then placed in fresh distilled water for 18 hours. The forty minutes' diffusate gave a ratio of $\frac{\mathrm{H}_{2} \mathrm{SO}_{4}}{\mathrm{Na}_{2} \mathrm{SO}_{4}}=25$, only a little lower than that shown by the original liquid. The 18 hours diffusate gave a ratio $\frac{\mathrm{H}_{2} \mathrm{SO}_{4}}{\mathrm{Na}_{2} \mathrm{SO}_{4}}=11 \cdot 8$. Evidently, then, the portions of the liquid which diffused last were much richer in sodium salt than the earlier ones.

This would show that a large proportion of sulphate of sodium is formed in close contact with the lead sulphate, and we have already seen that this is favourable to the reduction of that body.

But there is another consideration. It is well known that the spongy lead formed on one of the plates in a secondary battery is to some extent acted on by the liquid. 
It occurred to us that this direct chemical action between lead and sulphuric acid might be influenced by sodium sulphate. We therefore placed a quantity of red lead on a sheet of lead and reduced it electrolytically. The sheet was then cut into small pieces and divided into two equal quantities of about 20 grammes each. One half was put into a flask containing 1 volume of acid to 6 of water; the other half was put into a similar acid with the addition of 5 per cent. of sodium sulphate. Hydrogen gas was evolved from both flasks at the-ordinary temperature. The following Table shows the results :-

\begin{tabular}{|c|c|c|c|c|}
\hline \multirow{2}{*}{ Time, in days. } & \multicolumn{3}{|c|}{ Hydrogen collected, in cubic centimetres. } \\
\cline { 2 - 5 } & \multicolumn{2}{|c|}{ From Acid. } & From Acid containing Na, SO, \\
\cline { 2 - 5 } & Per diem. & Total. & Per diem. & Total. \\
\hline 1 & 160 & 160 & 116 & 116 \\
2 & 125 & 285 & 91 & 207 \\
3 & 120 & 405 & 87 & 294 \\
7 & 75 & 695 & 54 & 512 \\
\hline
\end{tabular}

It is evident that the sodium sulphate exercised a protecting influence on the lead.

In another experiment with a solution containing as small a proportion of sodium sulphate as that used by Mr. Preece, the protective influence was still observable, though much less marked.

These results support the idea that part of the effect produced by sodium sulphate lies in its power to diminish the local actions arising between the acid and the different parts of the plates.

It is not unlikely that this chemical action has something to do with the difficulty experienced in electrolytically reducing pure lead sulphate when that substance unmixed with other compounds is simply immersed in dilute acid; for at the moment of incipient decomposition the lead must be very finely divided, with its affinities in their most active state. 


\section{Sub-sulphate of Lead.}

In a paper read before the Royal Society ${ }^{*}$, Dr. Frankland doubts whether the lead sulphate formed and decomposed in the cell is the ordinary white sulphate known to chemists, and has studied the action of dilute acid on litharge and on minium. From litharge he obtained a buff-coloured compound, for the composition of which he gives the formula $\left(\mathrm{SO}_{3}\right)_{3}(\mathrm{PbO})_{5}$. From red lead he obtained a brownish-red compound, $\mathrm{S}_{2} \mathrm{~Pb}_{3} \mathrm{O}_{10}$. Dr. Frankland thinks it highly probable that one or other of these salts takes part in the electrolytic processes of the storage battery. He remarks, however, very truly that the working conditions in a battery are very different from those of his experiments.

With reference to these results we have made some observations.

Buff-coloured body from Litharge. -The formula $\left(\mathrm{SO}_{3}\right)_{3}$ $(\mathrm{PbO})_{6}$ can be written $2 \mathrm{PbO}+3 \mathrm{PbSO}_{4}$. In other words, the substance may either be a true sub-sulphate, or a mixture of the ordinary sulphate and oxide of lead. When attempting to prepare some of this compound, preliminary results suggested the following experiment.

Known quantities of litharge and sulphuric acid were digested together in a flask. From time to time the flasks were shaken vigorously and a small quantity of the clear liquid subtracted. The strength of the acid was carefully determined; and from this, together with the known volume of acid, it was easy to find how much acid had combined with the lead oxide. The curves given below, which are drawn through the actual points of observation, show the course of the action for 28 days, the ordinates giving the acid absorbed, and the abscisse the time.

In Exp. I., 33.41 grams of litharge and 150 cubic centim. of 1 to 5 acid were used. 'This liquid contained 43.38 grams of sulphuric acid

In Exp. II., 39.73 grams of litharge and 150 cubic centim. of 1 to 6 acid $=36 \cdot 37$ grams $\mathrm{H}_{2} \mathrm{SO}_{4}$ were used.

In Exp. III., 39.92 grams of litharge and 150 cubic centim. of 1 to 10 acid $=25$ grams $\mathrm{H}_{2} \mathrm{SO}_{4}$ were used.

* Proc. Roy. Soc, 1888. 
The acid required for total conversion of the litharge into sulphate would be,

$$
\begin{aligned}
& \text { In Exp. I. }=14.7 \text { grams. } \\
& \text { In Exp. II. }=17.45, \\
& \text { In Exp. III. }=17.54,
\end{aligned}
$$

Of course only thre fifths of these quantities would have been required to form the compound $\left(\mathrm{SO}_{3}\right)_{8}(\mathrm{PbO})_{5}$.

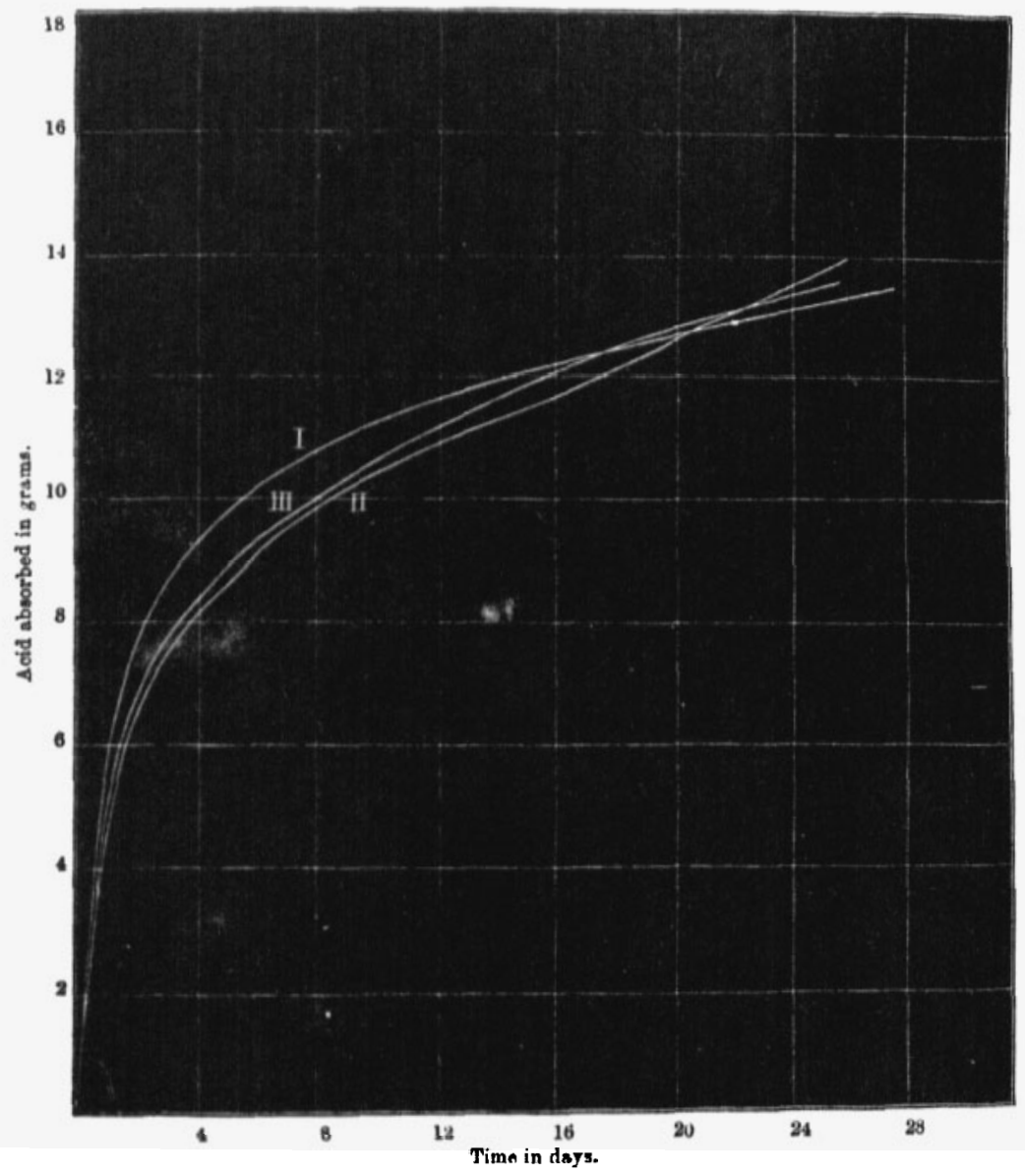

The salt gradually became white in colour. It is evident that in each case the action was slow and progressive, without any sudden change of rate to mark the formation of a sub-salt. 
At a later date we stopped the experiments and analysed the substances produced in Exps. I. and II.

In I. we found $31 \cdot 26$ per cent. of $\mathrm{SO}_{4}$, which indicates the presence of 98.6 per cent. $\mathrm{PbSO}_{4}$ and 1.4 per cent. of $\mathrm{PbO}$.

In II. we found 31.67 per cent. of $\mathrm{SO}_{4}$, which indicates 99.5 per cent. $\mathrm{PbSO}_{4}$ and 0.5 per cent. of $\mathrm{PbO}$.

The general outcome is clearly in favour of the idea that the action is a continuous one, which will only finish when the whole of the litharge is converted into sulphate. As the experiment proceeds there is an increasing proportion of insoluble sulphate present, which no doubts acts as a protective coat for the unchanged litharge, and thus renders the transformation less rapid. We found in fact that the action was greatly hastened if we continually broke up the substance in a mortar.

We see therefore no reason to doubt the view pat forth as far back as January 1882, that the substance produced in the voltaic reaction is ordinary sulphate of lead, a substance which is easily oxidated by means of the current, and is reduced without serious difficulty, especially when broken up by better conducting bodies.

\section{High Initial Electromotive Force.}

During the prosecution of the experiments described in the preceding pages our attention was again drawn to the high electromotive force which, as is well known, is found in a secondary battery for a short time after the charging current has been stopped. So far as we know, the explanations of this curious phenomenon which have been hitherto given are not looked upon as satisfactory. These explanations depend on the presence and action of electrolytic gases, which are either supposed to be occluded by the electrodes, or else to form secondary products differing from the ordinary elements in much the same way as ozone differs from oxygen.

We thought it probable that the chief cause of the high E.M.F. might be found in the great inequalities in the strength of acid produced by the charging current. There is no doubt that the acid becomes much stronger in the immediate vicinity of the peroxide plate. The strong and weak acid thus produced at the positive and negative plates respectively, being 
contained in spongy masses of material, require some time to diffuse, and the normal E.M.F. of 2 volts cannot be attained until diffusion has produced uniformity in the strength of the acid. We put this idea to experimental test.

Most of the observations were made on a small experimental cell in which were :-

(1) a negative plate consisting of a strip of lead ( 1 inch $\times 3$ ) covered with spongy lead;

(2) a positive plate made of similar lead covered with peroxide ;

(3) an electrolyte of dilute acid containing 18.5 per cent. $\mathrm{H}_{2} \mathrm{SO}_{4}$ (= 1 volume of acid to about 9 of water).

We also provided a small porous earthenware jar filled with stronger acid, into which we could introduce the peroxide plate when desired.

In the first series of experiments the plates were charged in the uniform electrolyte by a current of nearly half an ampere, and after breaking the battery-circuit, observations were taken of the E.M.F. by the condenser method.

\begin{tabular}{|c|c|c|c|c|}
\hline \multirow{2}{*}{$\begin{array}{l}\text { Time, after stopping the } \\
\text { charging current. }\end{array}$} & \multicolumn{4}{|c|}{ Electrumotive force, in volts. } \\
\hline & Exp. I. & Exp. II. & Exp. III. & Exp. IV. \\
\hline $\begin{array}{l}\text { At once } \ldots \ldots \ldots \ldots \ldots \ldots \ldots \\
5 \text { meconds } \ldots \ldots \ldots \ldots \ldots \ldots \ldots \\
1 \text { minute } \ldots \ldots \ldots \ldots \ldots \ldots \ldots \\
2 \text { minutes } \\
5\end{array}$ & $\begin{array}{l}\dddot{2} \cdot 16 \\
2 \cdot 13 \\
2 \cdot 06 \\
2 \cdot 01 \\
2 \cdot 00\end{array}$ & $\begin{array}{l}\ldots \ldots . \\
\dddot{2} \cdot 18 \\
2 \cdot 17 \\
2 \cdot 10 \\
2 \cdot 04 \\
2 \cdot 01\end{array}$ & $\begin{array}{l}\ddot{2} \cdot 17 \\
2 \cdot 16 \\
2 \cdot 10 \\
2 \cdot 02 \\
2 \cdot 01\end{array}$ & $\begin{array}{l}2 \cdot 58 \\
2 \cdot 28 \\
2 \cdot 14 \\
2 \cdot 12 \\
2 \cdot 06 \\
2 \cdot 05\end{array}$ \\
\hline \multicolumn{5}{|c|}{ Peroxide plate now put into the jar of stronger acid. } \\
\hline $\begin{array}{l}\text { Time after change of acid } \\
\text { round peroxide. }\end{array}$ & $\mid \begin{array}{c}\text { Acid } 34 \text { per } \\
\text { cent. }\end{array}$ & $\begin{array}{c}\text { Acid } 34 \text { per } \\
\text { cent. }\end{array}$ & Acid 34 per & $\begin{array}{c}\text { Acid } 58 \text { per } \\
\text { cent. }\end{array}$ \\
\hline 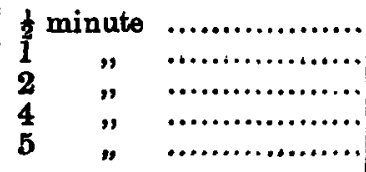 & $\begin{array}{l}2 \cdot 05 \text { volts. } \\
2 \cdot 07 ", \\
2 \cdot 07 " \\
2 \cdot 09 " \\
2 \cdot 10 "\end{array}$ & $\begin{array}{l}2 \cdot 06 \text { rolts. } \\
2 \cdot 09 ", \\
2 \cdot 12 ", \\
2 \ldots 3 "\end{array}$ & $\begin{array}{l}2 \cdot 05 \text { volts. } \\
2 \cdot 09 " \\
2 \cdot 12 " \\
\dddot{2} \cdot 13 "\end{array}$ & $\begin{array}{ll}2 \cdot 16 & \text { rolts. } \\
2 \cdot 20 & \text { " } \\
2 \cdot 21 & \text { " } \\
2 \cdot 24 & \text { " }\end{array}$ \\
\hline
\end{tabular}

From this Table it is evident that the rate of fall in the various experiments is fairly uniform, and also that an

* These strengths refer to the acid in the porous jar. That in the general body of the cell remained as befure -18.5 per cent.

VOL. $\mathrm{X}$. 
increase in the strength of the acid round the positive plate (peroxide) is able to give a large increase in the E.M.F. of the cell. We further see that the greater portion of the fall in E.M.F. takes place in the first few seconds after stopping the charging current. This we should expect if the action depends on differences of density in acid, for these differences will be greatest and diffusion most marked in the early stages. In the following set of experiments the spongy lead stood in 18.5 per cent. acid, while the porous jar containing the peroxide plate was filled with acid whose strength in Exps. I. and II. was 34 per cent., and in Exp. III. 58 per cent. The cell thus arranged was charged as before, and after stopping the charging current observations were taken of the E.M.F.

\begin{tabular}{|c|c|c|c|}
\hline \multirow{2}{*}{$\begin{array}{l}\text { Time, after stopping the } \\
\text { charging current. }\end{array}$} & \multicolumn{3}{|c|}{ Electromotive force, in rolts. } \\
\hline & Exp. I. & Exp. II. & Exp. III. \\
\hline 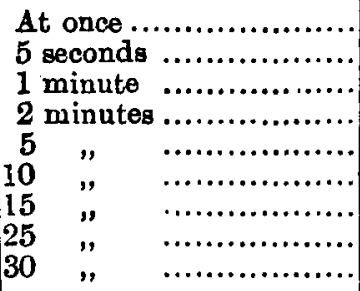 & $\begin{array}{l}2 \cdot 61 \\
\dddot{2} \cdot 2 \cdot \\
2 \cdot 21 \\
2 \cdot 18 \\
2 \cdot 17 \\
2 \cdot 14 \\
\ldots \ldots\end{array}$ & $\begin{array}{c}\ldots \ldots \\
\ldots \ldots . \\
2 \cdot 24 \\
2 \cdot 23 \\
2 \cdot 21 \\
2 \cdot 20 \\
2 \cdot 16 \\
\ldots \ldots . \\
\ldots \ldots .\end{array}$ & $\begin{array}{l}2 \cdot 61 \\
\mathbf{2} \cdot 44 \\
2 \cdot 33 \\
2 \cdot 31 \\
2 \cdot 28 \\
2 \cdot 28 \\
2 \cdot 27 \\
2 \cdot 27 \\
\mathbf{2} \cdot 25\end{array}$ \\
\hline
\end{tabular}

From this Table it appears that the rate of fall is very much slower than before. This is especially marked in Exp. III., where the strength of the acid in the jar is nearer the possible maximum producible in the interstices of the spongy materials.

It may be worth notice, that the value of the E.M.F. to which the cells finally rise in Exps. I., II., and III. of the first series is very nearly the same as that to which they fall in the first two experiments of the second series. If the rise is due, as we think, to the diffusion inwards of the stronger acid, some such agreement might be expected.

We therefore regard the abnormal E.M.F. as due to the nequality of acid strength, and its gradual disappearance as due to equalization of strength produced by diffusion. 